\title{
Preparation and Characterization of Nanocrystalline CuS Thin Films for Dye-Sensitized Solar cells
}

\author{
M. A. Sangamesha, ${ }^{1}$ K. Pushpalatha, ${ }^{1}$ G. L. Shekar, ${ }^{2}$ and S. Shamsundar ${ }^{3}$ \\ ${ }^{1}$ Department of Chemistry, The National Institute of Engineering, Mysore, Karnataka 570008, India \\ ${ }^{2}$ Department of Industrial Production and Engineering, The National Institute of Engineering, Mysore, Karnataka 570008, India \\ ${ }^{3}$ Department of Mechanical Engineering, The National Institute of Engineering, Mysore, Karnataka 570008, India
}

Correspondence should be addressed to K. Pushpalatha; kplnie@hotmail.com

Received 1 June 2013; Accepted 1 July 2013

Academic Editors: W. Bao, Z. Jiang, X. Li, W. W. Shu, and Y. Zhang

Copyright (C) 2013 M. A. Sangamesha et al. This is an open access article distributed under the Creative Commons Attribution License, which permits unrestricted use, distribution, and reproduction in any medium, provided the original work is properly cited.

A dye-sensitized nanocrystalline copper sulphide $(\mathrm{CuS})$ solar cell is developed using crystal violet $(\mathrm{CV})$ as a photosensitizer. Nanocrystalline CuS thin film is deposited on indium tin oxide- (ITO-) coated glass substrate by chemical bath deposition (CBD) technique. These thin films are characterized for their structural, optical and electrical properties using X-ray diffractometer (XRD), atomic force microscopy (AFM), and scanning electron microscopy (SEM). Optical absorbance measurements from UV-visible spectrometer at normal incidence of light in the wavelength range of 320-1100 nm and current-voltage (I-V) measurements were also made. The deposited CuS thin film on ITO-coated glass substrate may be used as a photo electrode in the fabrication of dyesensitized solar cell (DSSC). The carbon soot collected on the substrate is used as a counter electrode. The counter electrode coupled with a dye-sensitized $\mathrm{CuS}$ thin film along with a redox electrolyte mixture is used to develop a complete photovoltaic cell. The fill factor and efficiency were evaluated for the developed DSSC.

\section{Introduction}

Recent research on solar cells has been aimed at lowering the fabrication cost to decrease the price of the energy obtained. In this context, suitable materials should be easily preparable, inexpensive, and must show stable behavior over a long period of operation. The photo electrochemical (PEC) cells provide an economic chemical route for trapping solar energy. Beside the PEC cell, the semiconductor-electrolyte interface may be used for photoelectrolysis, photocatalysis, and photoelectrochemical power generation [1]. Thus the PEC cells composed of dye-sensitized oxides have also been widely investigated. Several natural pigments [2] and synthesized dyes [3] have been identified to fabricate the solar cells. The dye-sensitized (DS) PEC cell based on nanocrystalline $\mathrm{TiO}_{2}[4]$ and the DSSC with solid hole collectors are reported elsewhere [5]. Nanocrystalline metal sulphide such as copper sulphide (CuS), deposited as a thin film on the different substrates, is considered as a promising material for solar energy conversation system, due to their structural and electrical properties [6]. It is used in a variety of applications, namely, as gas sensor [7] and optoelectronic devises as reported by Nair et al. $[6,8]$. Several techniques have been used to produce copper sulphide thin films such as spray pyrolysis $[9,10]$, successive ionic layer absorption and reaction techniques [11], photochemical deposition [12], elctrodeposition [13], and chemical bath deposition [13-16]. Among them the chemical bath deposition (CBD) method is attractive since the technique possesses a number of advantages over conventional thin film deposition methods. CBD technique is used for producing a thin film of copper sulphide, and the effect of time on deposition at various concentrations is also studied [17]. The effects of film thickness on structural, optical, and electrical properties of the as-deposited nanocrystalline copper sulphide thin films [18] and fabrication CuS films at high temperature and its effect on optical property of the film [19] have also been reported. This technique is the most cost saving and convenient to produce various chalcogenide thin films such as $\mathrm{In}_{2} \mathrm{~S}_{3}$ [20], CdSe [21], SnS [22], and FeS [23]. It makes use of the fact that film can be deposited on 
a suitable substrate by dipping them in a suitable solution bath containing metal salts without applying any external field. Even though there are physical techniques which are more suitable for the growth of uniform and high-quality thin films, they are expensive and require more efforts, whereas chemical methods are economical and simple.

In the present report, an attempt is made to develop a nanocrystalline copper sulphide thin film on ITO-coated glass substrate by CBD technique. For the first time CV organic dye (a photosensitizer) is adsorbed over $\mathrm{CuS}$ thin film for the development of a DSSC. The surface morphological, structural, and optical properties of the fabricated layer have been studied using atomic force microscopy (AFM), scanning electron microscopy (SEM), X-ray diffraction (XRD), and UV-visible spectrophotometer. Power output characteristics like I-V characteristics and fill factor of the developed DSSC are also investigated.

\section{Experimental}

2.1. Preparation of CuS Thin Films. Substrate cleaning plays an important role in the deposition of thin films, because contaminated surface of the substrates results in the nonuniform film growth. Therefore, ITO-coated glass slides of the dimensions $15 \times 10 \times 1 \mathrm{~mm}$ were cleaned in an isopropyl alcohol using ultra bath sonicator for about 10-15 minutes and subsequently washed with distilled water. Later, substrates were dried in an oven at $100^{\circ} \mathrm{C}$.

The thin film of $\mathrm{CuS}$ is fabricated by $\mathrm{CBD}$ technique $[7,24]$. Copper sulphate $\left[\mathrm{CuSO}_{4} \cdot 5 \mathrm{H}_{2} \mathrm{O}\right]$ (99.9\% Merck), thiourea $\left[\mathrm{SC}\left(\mathrm{NH}_{2}\right)_{2}\right]$ (99.9\% Sigma Aldrich), triethanolamine $\left[\mathrm{N}\left(\mathrm{CH}_{2} \mathrm{CH}_{2} \mathrm{OH}\right)_{3}\right](98 \%$ SDFCL), and ammonia solution of analytical grade were used as received. Aqueous solution of copper sulphate, thiourea, and triethanolamine were prepared separately using double-distilled water before the experiment. $0.1 \mathrm{M} \mathrm{CuSO}_{4} \cdot 5 \mathrm{H}_{2} \mathrm{O}$ solution was taken in a beaker; other ingredients such as 1:1 triethanolamine of $2.5 \mathrm{~mL}, 1 \mathrm{M}$ thiourea of $5 \mathrm{~mL}$, and $5 \mathrm{~mL}$ of $30 \%$ ammonia solution $\left(\mathrm{NH}_{3}\right)$ were added slowly one after the other with constant stirring. The bath solution was diluted to $50 \mathrm{~mL}$ using double-distilled water. The triethanolamine serves as a complexing agent to chelate with copper ions. The deposition of $\mathrm{CuS}$ films is based on the slow release of $\mathrm{Cu}^{2+}$ and $\mathrm{S}^{2-}$ ions in the solution, which are then condensed on to the glass substrates [25]. The thiourea was used as a source for sulphide ions, and ammonia solution is used to maintain the $\mathrm{pH}$ of the bath at 11. The deposition of $\mathrm{CuS}$ thin film on glass substrate using suitable bath solution containing copper ions at $1.5 \mathrm{pH}$ is also reported [26]. Here, previously cleaned ITO-coated glass slides were immersed vertically in the bath for $5 \mathrm{~h}$ at lab temperature (or $300 \mathrm{~K}$ ) without stirring the solution during the deposition. After the deposition, the substrates were taken out and washed with doubly distilled water and annealed at $250^{\circ} \mathrm{C}$ for $2 \mathrm{~h}$ in a vacuum annealing chamber.

2.2. Cell Preparation. For fabrication of the complete cell, the adsorption of dye was carried out on the thin film of $\mathrm{CuS}$ immediately after annealing to avoid the rehydration

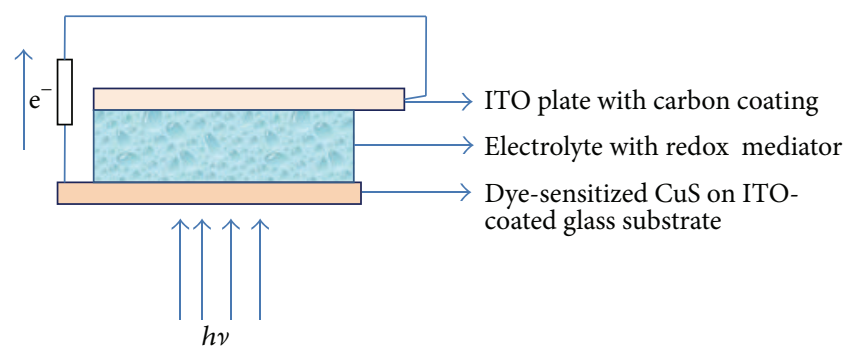

FIGURE 1: Schematic representation of the DSSC.

of the thin films. The procedure reported by Reda and ElSherbieny [27] is adopted here for the adsorption of the dye on $\mathrm{CuS}$ thin film. The CV dye solution purchased from Rankem is used as such. The ITO-coated $\mathrm{CuS}$ film was dipped in dye solution at room temperature for $12 \mathrm{~h}$. After the complete adsorption of the dye, for the first time the carbon counter electrode was prepared by collecting the carbon soot on the ITO-coated conducting glass slide. This counter carbon electrode was placed over the CV dye-coated electrode, and the edges of the cell were sealed to complete the fabrication of DSSC. A redox electrolyte consisting of a mixture of iodide/triiodide in acetonitrile was injected using a syringe into the space between the two electrodes. A schematic representation of the cell is shown in Figure 1. The area of the cell was $1.5 \mathrm{~cm}^{2}$ (i.e., $1 \mathrm{~cm} \times 1.5 \mathrm{~cm}$ ).

2.3. Thin Film Characterization. For the analysis of particle structure, X-ray diffractometry (XRD) was conducted using Bruker AXS model D8 Germany. The structural property of the film was investigated by X-ray diffraction using $\mathrm{CuK} \alpha$ radiation of wavelength $(\lambda)=1.5406 \AA$. Surface morphology was observed using Phenom scanning electron microscope (SEM). The surface of the film was examined by an atomic force microscope (AFM, PARK system). The AFM was operated in tapping mode to avoid destruction due to the use of a standard silicon tip. Optical properties were studied by measuring absorbance of the film using shimadzu spectrophotometer within the wave length range of 320-1100 nm. The power output characteristic of a developed cell was studied by using the lab-equipped I-V measurement system. The measurements of current and voltages were in $\mu$-amps and millivolts, respectively.

\section{Results and Discussion}

3.1. Surface Morphology of the Thin Film. The scanning electron microscopy (SEM) obtained for the fabricated thin film of $\mathrm{CuS}$ is shown in Figures 2(a)-2(d). SEM is a promising technique for the study of morphology of thin films. It gives important information regarding growth, shape, and size of the particles. Figures 2(a)-2(d) show the SEM micrographs obtained at different magnifications before and after adsorption of $\mathrm{CV}$ dye on $\mathrm{CuS}$ thin film. It is observed from Figures 2(a) and 2(b) that the grains are relatively good, compact, 


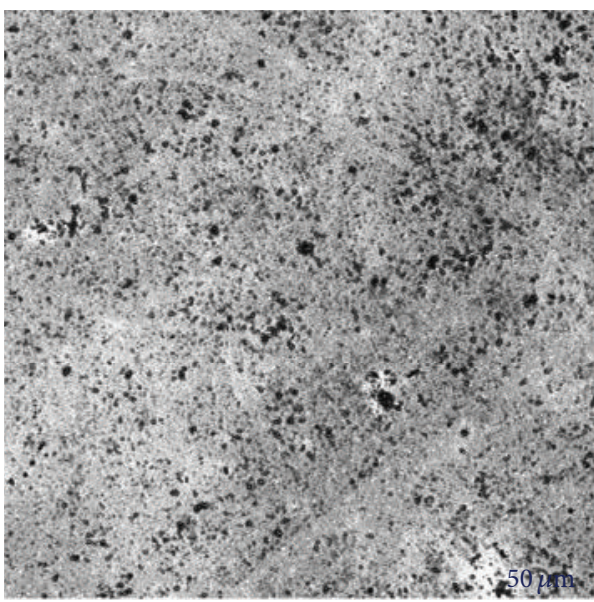

(a)

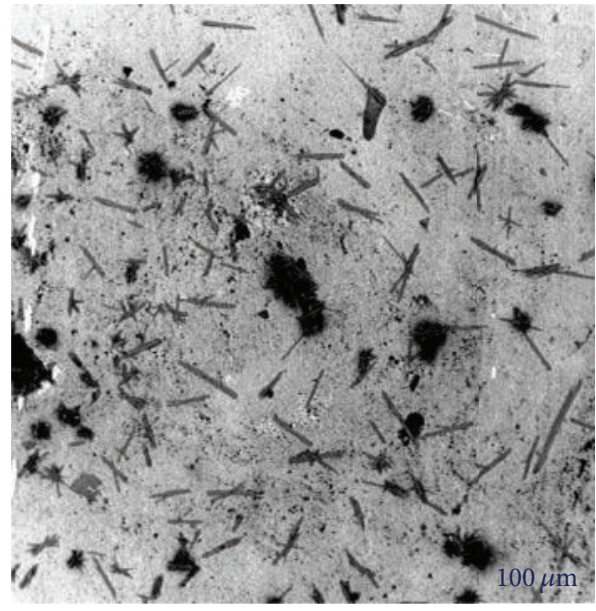

(c)

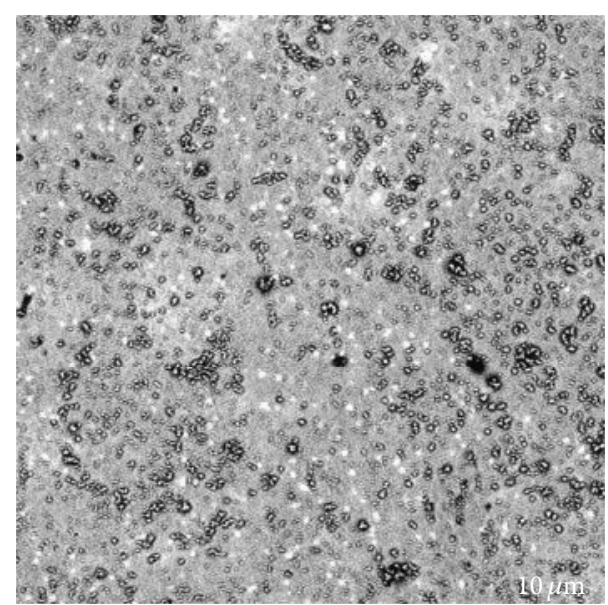

(b)

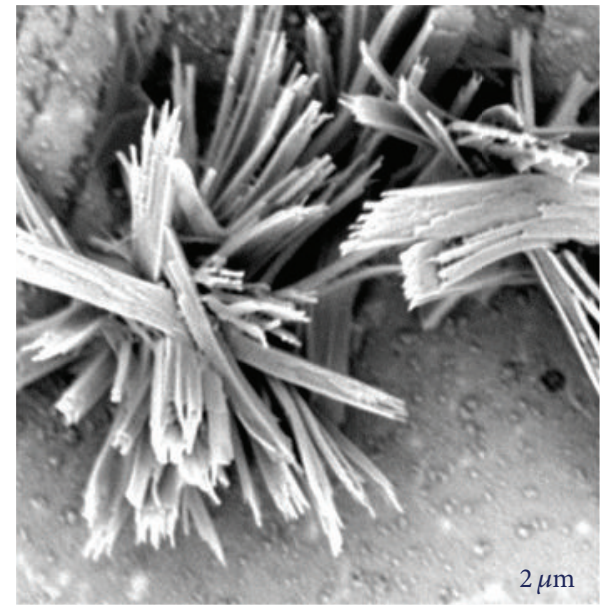

(d)

FIGURE 2: SEM images of CuS thin film on ITO-coated glass substrate at different magnifications ((a) and (b)) before dye adsorption and ((c) and (d)) after dye adsorption.

homogeneous, and uniformly covered. It is to be noted that before the adsorption of CV dye, the particles are spherical and uniformly distributed whereas after the adsorption of dye on the thin film, cluster formation is observed as shown in Figures 2(c) and 2(d). This may be due to aggregated CV clusters.

An atomic force microscope (AFM) was used to study the surface morphologies of the CuS film fabricated on the ITO-coated glass substrate. It gives the particle size, structure, thickness, and surface roughness. This technique is capable of mapping three-dimensional images of the surface. Figures $3(\mathrm{a})$ and $3(\mathrm{c})$ are the two-dimensional (2D) images whereas Figures 3(b) and 3(d) corresponds to 3D images of $\mathrm{CuS}$ thin film before and after dye sensitization. From the AFM image, it is found that these thin films are uniform, without cracks and consists of spherical nanosize particles which are well adhered to the substrate. The thickness of the film is found to be $250 \mathrm{~nm}$. After CV dye adsorption the AFM pictures obtained were blurry. We believed that this is because the $\mathrm{CV}$ molecules were accumulated into clusters. The root mean square (rms) roughness is defined as the standard deviation of the surface height profile from the average height and is the most commonly reported measurement of surface roughness. The surface rms roughness of the film is $30 \mathrm{~nm}$, and this roughness is unavoidable since the particles are spherical in shape. The observed rms roughness deviates from the reported value which may be due to various reasons like deposition time, solvent used, anisotropy of surface energy, and so forth $[28,29]$.

3.2. Structure Characterization. The XRD patterns obtained for the synthesized $\mathrm{CuS}$ thin film on glass substrate are as shown in Figure 4. The patterns show well-defined peaks suggesting that the film is crystalline. A comparison of the observed peaks of $\mathrm{CuS}$ at $2 \theta$ positions indicates the typical Covellite structure [7] whereas the presence of secondary phase of $\mathrm{Cu}_{9} \mathrm{~S}_{5}$ is also indicated in the figure, and the planes which corresponds to these diffraction angles are closely corresponding to Deginite structure [30, 31]. 


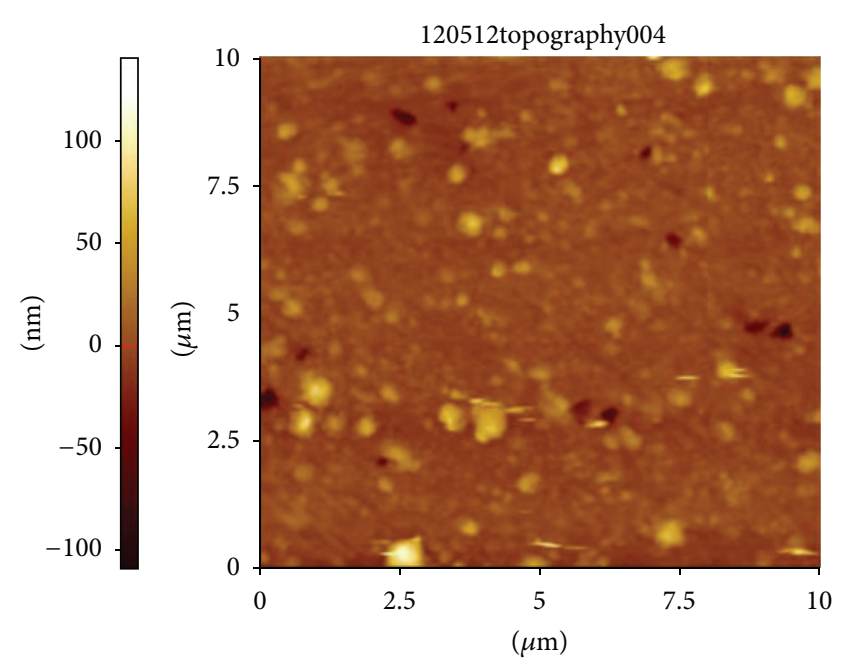

(a)

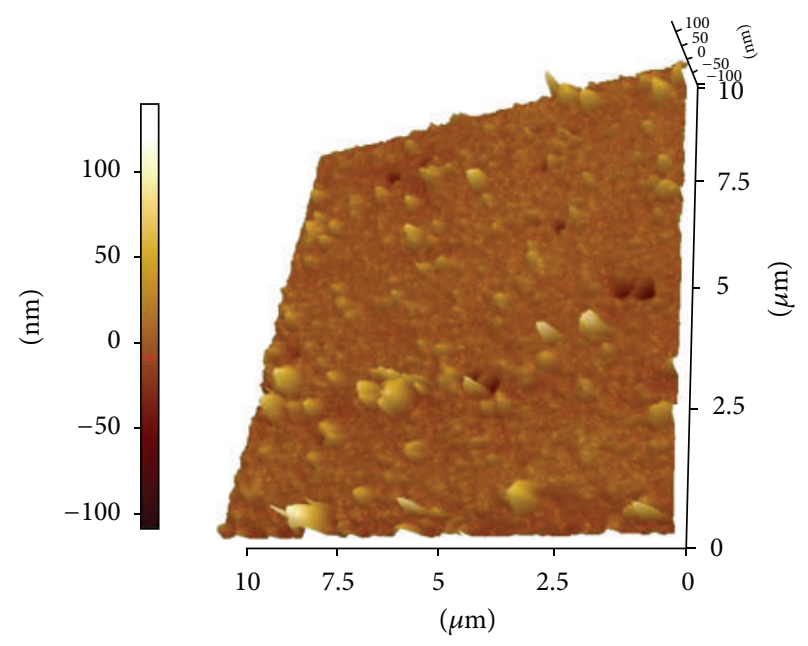

(c)

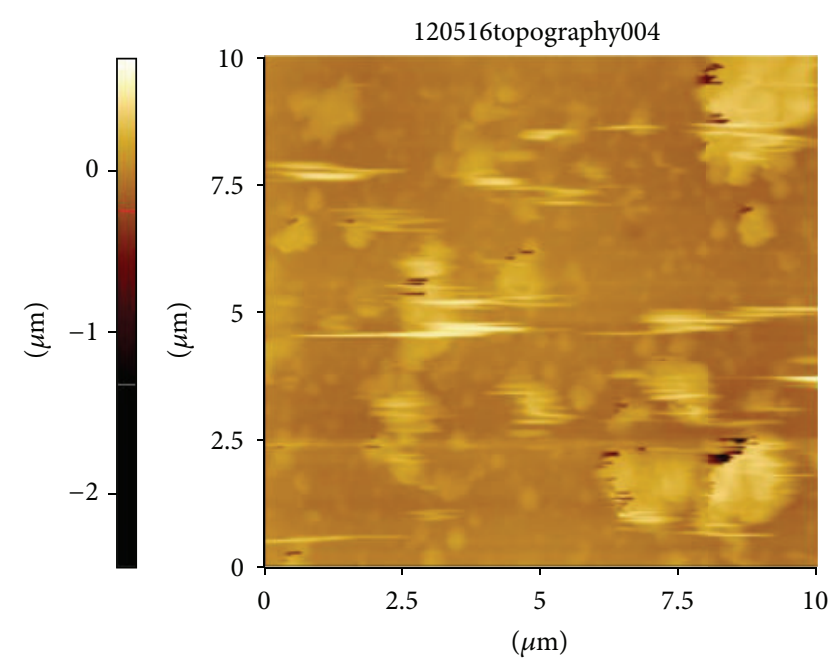

(b)

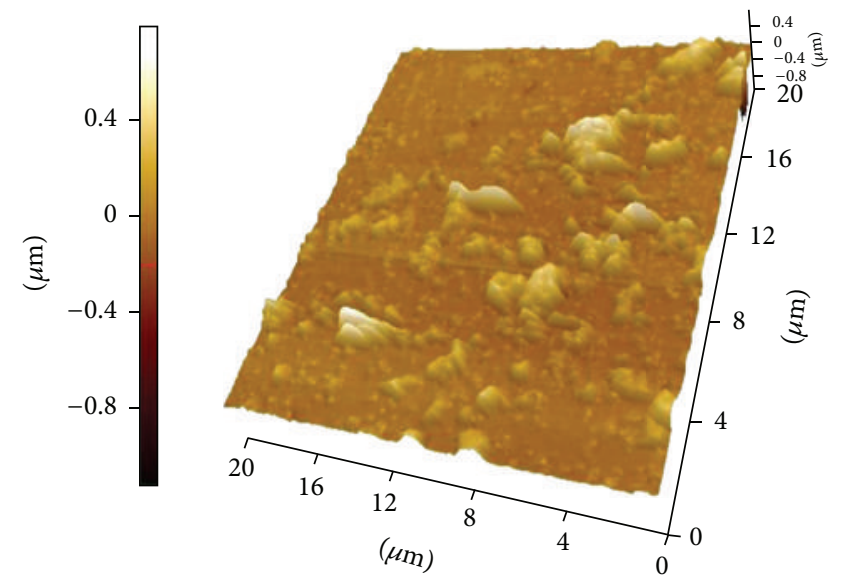

(d)

Figure 3: Two-dimensional ((a) and (c)) and 3-dimensional ((b) and (d)) AFM images of CuS thin film.

The average size of the particles can be calculated from the full width of half maximum (FWHM) values of the diffraction peaks using Debye-Scherrer formula [32]

$$
D=\frac{0.94 \lambda}{\beta \cos \theta},
$$

where $D$ is the average crystallite size, $\lambda$ the $\mathrm{X}$-ray wavelength of $\mathrm{CuK}_{\alpha}$ radiation $(0.154 \mathrm{~nm}), \theta$ the diffraction angle, and $\beta$ the FWHM. The size of the nanoparticle estimated at $2 \theta=$ $32.26^{\circ}$ from (1) is $2.38 \mathrm{~nm}$. This indicates that the crystallite size is very small. The corresponding XRD data, that is, interplanar distance " $d$ ", relative intensities, and calculated particle sizes are presented in Table 1 . When the particle size is very small, appreciable broadening in X-ray diffraction lines will occur, and this depends on the particle size and strain [32]. Intensity of the peaks obtained here is much higher compared to the XRD pattern reported elsewhere, and the calculated average particle size is $19.7 \mathrm{~nm}$ for $\mathrm{CuS}$, which is comparable with the average grain size of $\operatorname{In}_{2} \mathrm{Se}_{3}$ [33].

3.3. Optical Characterization of the Film. Figure 5 shows the absorption spectra of CuS thin film before and after sensitization by $\mathrm{CV}$ dye. The absorption spectrum for $\mathrm{CuS}$ thin films was recorded in the wavelength region from $320 \mathrm{~nm}$ to $1100 \mathrm{~nm}$. The deposited CuS thin films are having high absorbance in the UV region and low absorbance in the visible region as it can observe from UV spectrum before dye adsorption and a broad absorption peak located at nearly $430 \mathrm{~nm}$ to $700 \mathrm{~nm}$ in the visible region after the adsorption of $\mathrm{CV}$ dye on the $\mathrm{CuS}$. The absorption edge of $\mathrm{CuS}$ is between 450 and $550 \mathrm{~nm}$; after the dye sensitization it is shifted to $670 \mathrm{~nm}$. An absorption edge corresponds to an electron excited by a photon of energy, whereby electron can jump from a lower energy to a higher energy state. However after dye sensitization, high absorption is shown by $\mathrm{CuS}$ thin film in the visible region, and also indicates the red shift. This shift 
TABLE 1: The grain size calculated from Debye-Scherrer formula.

\begin{tabular}{lcccc}
\hline Angle $(2 \theta)$ & $d(\AA)$ & Intensity (counts) & FWHM of peak $(\beta)$ in degrees & Size of the particle $(D)$ in nm \\
\hline 28.03 & 3.18 & 604 & 0.5128 & 17.87 \\
32.26 & 2.77 & 1657 & 3.4874 & 2.38 \\
37.20 & 2.41 & 76.8 & 0.2468 & 34.84 \\
46.37 & 1.95 & 259 & 0.5370 & 16.40 \\
54.83 & 1.67 & 54 & 0.2665 & 26.76 \\
\hline
\end{tabular}

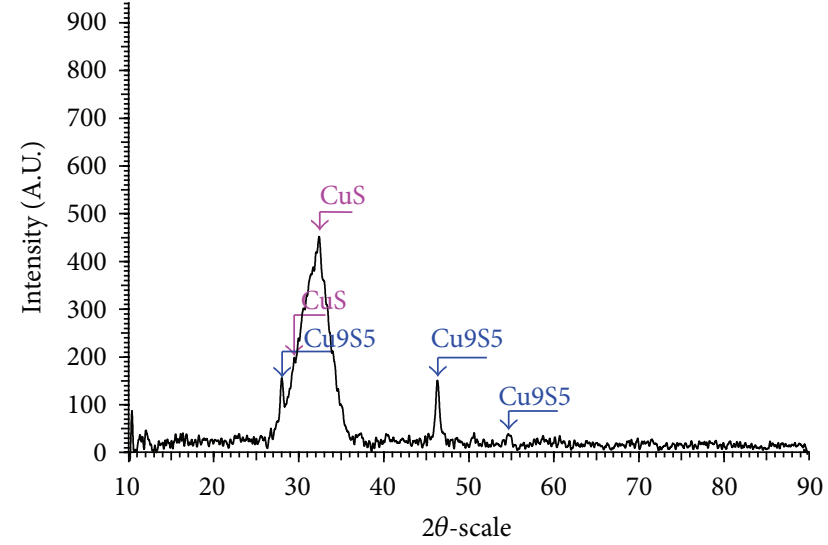

FIGURE 4: X-ray diffraction pattern of CuS thin film developed by CBD.

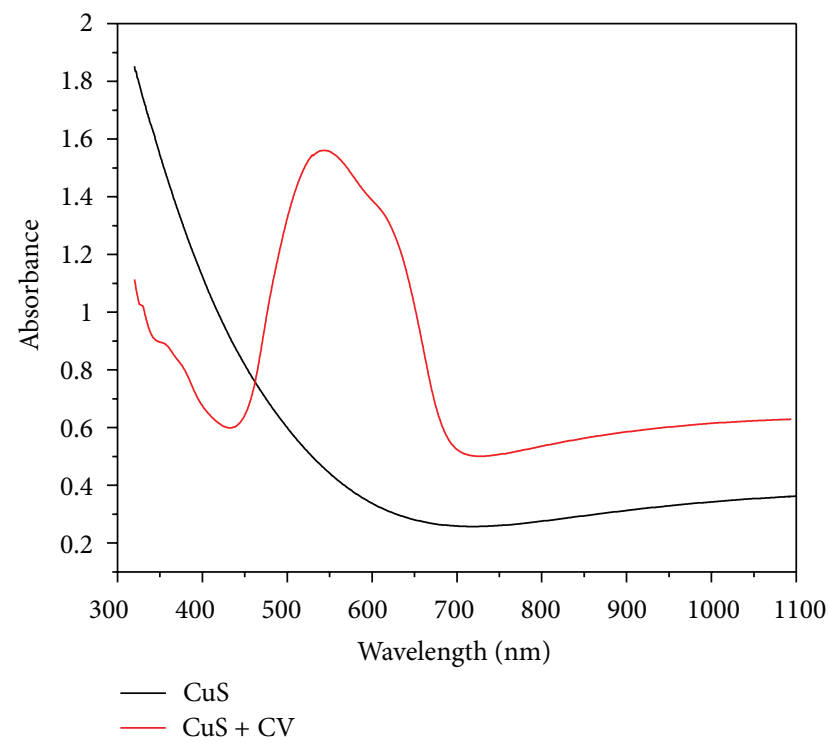

FIGURE 5: Absorption spectra of CuS thin film.

in absorption edge is maybe due to quantum confinement effects [27]. This helps DSSC to trap the photon energy in the entire UV-VIS spectral region.

The optical band gap $\left(E_{g}\right)$ of the prepared CuS was calculated by using the relation $[34,35]$

$$
(\alpha h v)=a\left(h v-E_{g}\right)^{n}
$$

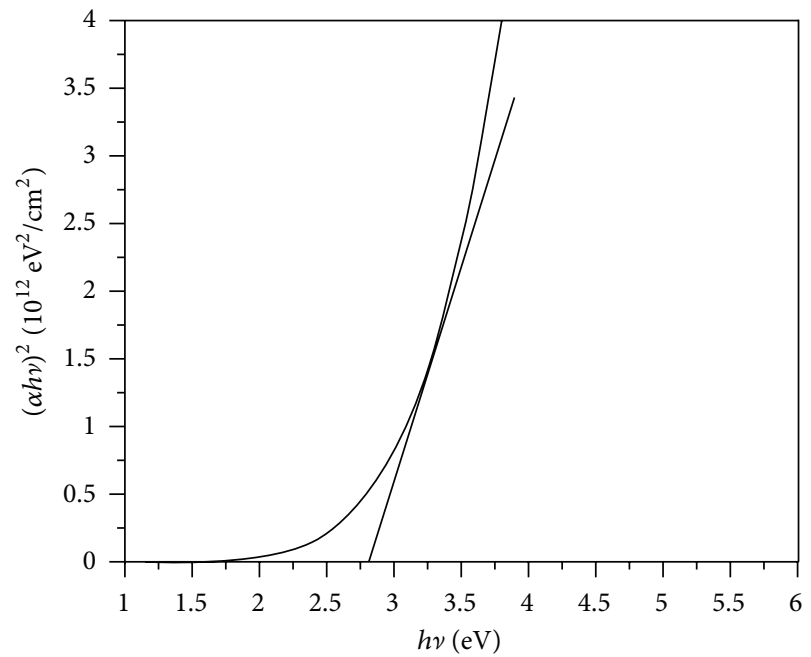

FIGURE 6: $(\alpha h \nu)^{2}$ versus $h \nu$ plot of CuS thin film obtained by CBD technique on ITO coated glass substrate.

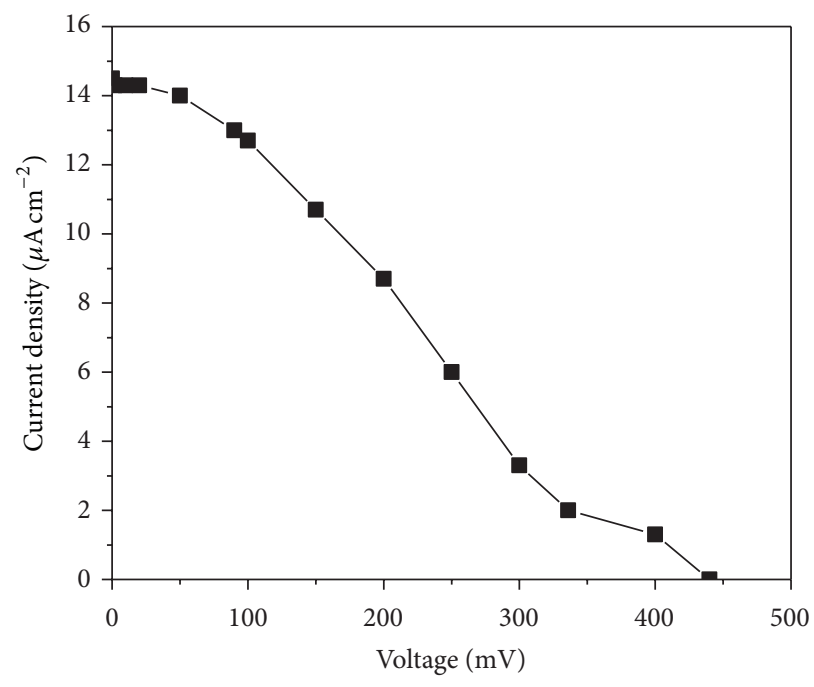

FIgURE 7: Current-voltage for CuS DSSC.

where $\alpha$ is the optical absorption coefficient, " $a$ " is a constant, and $n$ depends on transition type. The value of $\alpha$ is obtained from the following relation [36]:

$$
\alpha=2.303 \frac{A}{t}
$$


where $A$ is the absorbance and $t$ is the thickness of the film. The $(\alpha h \nu)^{2}$ is plotted as a function of photon energy $(h \nu)$ is shown in Figure 6. It varies almost linearly with photon energy above the band gap energy $\left(E_{g}\right)$. Thus, (2) can be applied for a direct interband transmission [37]. The linear extrapolation of this curve to the energy axis gives the value of band gap of $\mathrm{CuS}$ thin film as $2.8 \mathrm{eV}$ which closely agrees with the reported value [7].

3.4. Photovoltaic Measurements. The power output characteristics for a DSSC having the configuration: dye-sensitized $\mathrm{CuS} /$ iodide electrolyte/carbon electrode, was studied under illumination using halogen light source at lab temperature. The illuminated area is $1.5 \mathrm{~cm}^{2}$. The open circuit voltage $\left(V_{\mathrm{oc}}\right)$ is $440 \mathrm{mV}$ and short circuit current $\left(I_{\mathrm{sc}}\right)$ is $22 \mu \mathrm{A}$ which were measured for the device under illumination. These are the critical parameters required for the calculation of solar cell efficiency. The microammeter does not play any role at the time of short circuit current measurement, and voltmeter does not play any role at the time of measurement of open circuit voltage. By changing the variable resistance the current and voltage were measured. Figure 7 is obtained by plotting the current density versus voltage.

The power conversion efficiency of the cell was calculated using (4), where $P_{\text {in }}$ is the incident intensity of light and FF is the fill factor

$$
\eta=\frac{I_{\mathrm{sc}} * V_{\mathrm{oc}} * \mathrm{FF}}{P_{\mathrm{in}}} \times 100
$$

The maximum power output of the cell is given by the largest rectangle that can be drawn inside the curve. The fill factor (FF) is calculated using (5), where $I_{\mathrm{mp}}$ and $V_{\mathrm{mp}}$ are the current and voltage, respectively, for the maximum power output. The values of $I_{\mathrm{mp}}=9.6 \mu \mathrm{A} / \mathrm{cm}^{2}$ and $V_{\mathrm{mp}}=180 \mathrm{mV}$ (cf. Figure 7)

$$
\mathrm{FF}=\frac{I_{\mathrm{mp}} * V_{\mathrm{mp}}}{I_{\mathrm{sc}} * \mathrm{~V}_{\mathrm{oc}}}
$$

The calculated values of fill factor and power conversion efficiency for the device are $27.1 \%$ and $0.34 \%$, respectively. The result obtained indicates that the prospects are good for using organic dye as a photosensitizer in DSSCs. The power conversion value for similar type of dye-substituted photovoltaic device in presence of $\mathrm{C}_{60}$ [38], for dye-sensitized $\mathrm{ZnS}$ cell [39], is low when compared with our value reported here. However, photo properties of this device are not comparable with other sensitized solid-state devices [40-42]. Poor performance of this may be due to inefficient charge separation at the photo electrode-electrolyte interface, or the photo-generated electrons may leak out into the electrolyte instead of flowing through the external circuit results in low fill factor.

\section{Conclusions}

CuS thin films were successfully deposited on ITO-coated glass substrate by CBD, and it was used to fabricate a dyesensitized CuS solar cell. The SEM images show that the deposited thin film has uniform grain size and compact. The AFM measurements have shown that the $\mathrm{CuS}$ thin film has high roughness. The deposited thin film is homogeneous, uniform, well adhered, without any cracks, and covers the entire substrate surface area. The XRD patterns obtained confirm the Covellite structure to be the main phase in the $\mathrm{CuS}$ thin film which would be preferable for the fabrication of solar cells and also indicate the presence of secondary phase of $\mathrm{Cu}_{9} \mathrm{~S}_{5}$ which closely corresponds to Deginite structure. Even though SEM and AFM show that the particle size of $\mathrm{CuS}$ is more than $1 \mu \mathrm{m}$, the average crystallite size (D) of CuS was found to be $19.7 \mathrm{~nm}$. It is due to the fact that each solid compact cluster is made of number of particles having diameter in the range of nanometer. Optical measurements revealed a red shift in the absorption spectrum, which may be due to quantum confinement effects. Further, it helps to trap more photon energy in the UV-VIS region. Optical studies revealed that the film has direct allowed transition with band gap of $2.8 \mathrm{eV}$. The results obtained from photovoltaic measurements showed the short circuit photocurrent density of the cell made from dye-sensitized CuS. This film was found to be 14.5 micro amperes, and fill factor and efficiency of the developed DSSC will be $27.1 \%$ and $0.34 \%$, respectively. Even though there are many other known solar cells with high efficiency, still the dye-sensitized solar cells find much importance in photovoltaic devices due to the fact that this chemical method can be utilized for the production of $\mathrm{CuS}$ in large scale at very low cost.

\section{Acknowledgment}

The authors wish to thank the Vision Group on Science and Technology, Department of Information Technology, Biotechnology \& Science and Technology, Government of Karnataka, for extending the financial support under VGSTCESEM project.

\section{References}

[1] V. V. Killedar, C. D. Lokhande, and C. H. Bhosale, "(Photo) electrochemical studies on spray deposited $\mathrm{Bi}_{2} \mathrm{~S}_{3}$ thin films from non-aqueous media," Indian Journal of Pure and Applied Physics, vol. 36, no. 11, pp. 643-647, 1998.

[2] P. M. Sirimanne, E. V. A. Premalal, P. K. D. D. P. Pitigala, and K. Tennakone, "Utilization of MEH-PPV as a sensitizer in titanabased photovoltaic cells," Solar Energy Materials and Solar Cells, vol. 90, no. 11, pp. 1673-1679, 2006.

[3] A. Baheti, P. Tyagi, K. R. J. Thomas, Y. C. Hsu, and J. T. Lin, "Simple triarylamine-based dyes containing fluorene and biphenyl linkers for efficient dye-sensitized solar cells," Journal of Physical Chemistry C, vol. 113, no. 20, pp. 8541-8547, 2009.

[4] B. O’Regan and M. Gratzel, "A low-cost, high-efficiency solar cell based on dye-sensitized colloidal $\mathrm{TiO}_{2}$ films," Nature, vol. 353, pp. 737-740, 1991.

[5] G. R. R. A. Kumara, A. Konno, G. K. R. Senadeera, P. V. V. Jayaweera, D. B. R. A. de Silva, and K. Tennakone, "Dyesensitized solar cell with the hole collector p-CuSCN deposited from a solution in n-propyl sulphide," Solar Energy Materials and Solar Cells, vol. 69, no. 2, pp. 195-199, 2001. 
[6] P. K. Nair and M. T. S. Nair, "Chemically deposited SnS-Cu $\mathrm{Cu}_{x}$ thin films with high solar absorptance: new approach to all-glass tubular solar collectors," Journal of Physics, vol. 24, no. 1, p. 83, 1991.

[7] A. A. Sagade and R. Sharma, "Copper sulphide $\left(\mathrm{Cu}_{x} \mathrm{~S}\right)$ as an ammonia gas sensor working at room temperature," Sensors and Actuators B, vol. 133, no. 1, pp. 135-143, 2008.

[8] P. K. Nair, V. M. Garcia, A. M. Fernandez, H. S. Ruiz, and M. T. S. Nair, "Optimization of chemically deposited $\mathrm{Cu}_{x} \mathrm{~S}$ solar control coatings," Journal of Physics D, vol. 24, no. 3, pp. 441-449, 1991.

[9] L. A. Isac, A. Duta, A. Kriza, M. Nanu, and J. Schoonman, "Crystal order in $\mathrm{Cu}_{2} \mathrm{~S}$ thin films obtained by spray pyrolysis," Journal of Optoelectronics and Advanced Materials, vol. 9, no. 5, pp. 1265-1268, 2007.

[10] P. V. Nho, P. H. Ngan, N. Q. Tien, and H. D. Viet, "Preparation and characterization of low resistivity $\mathrm{CuS}$ films using spray pyrolysis," Chalcogenide Letters, vol. 9, no. 10, pp. 397-402, 2012.

[11] B. Guzeldir, M. Saglam, and A. Ates, "Deposition and characterization of CdS, CuS and ZnS thin films deposited by SILAR method," Acta Physica Polonica A, vol. 121, no. 1, pp. 33-35, 2012.

[12] J. Podder, R. Kobayashi, and M. Ichimura, "Photochemical deposition of $\mathrm{Cu}_{x} \mathrm{~S}$ thin films from aqueous solutions," Thin Solid Films, vol. 472, no. 1-2, pp. 71-75, 2005.

[13] C. Wu, J. B. Shi, C. J. Chen et al., "Synthesis and optical properties of $\mathrm{CuS}$ nanowires fabricated by electrodeposition with anodic alumina membrane," Materials Letters, vol. 62, no. 6-7, pp. 1074-1077, 2008.

[14] E. Güneri and A. Kariper, "Optical properties of amorphous $\mathrm{CuS}$ thin films deposited chemically at different $\mathrm{pH}$ values," Journal of Alloys and Compounds, vol. 516, pp. 20-26, 2012.

[15] S. U. Offiah, P. E. Ugwoke, A. B. C. Ekwealor, S. C. Ezugwu, R. U. Osuji, and F. I. Ezema, "Structural and spectral analysis of chemical bath deposited copper sulfide thin films for solar energy conversions," Digest Journal of Nanomaterials and Biostructures, vol. 7, no. 1, pp. 165-173, 2012.

[16] A. K. Singh, S. Mehra, and G. S. Thool, "Synthesis of copper sulphide $(\mathrm{CuS})$ thin film by chemical bath deposition method and its characterization," European Chemical Bulletin, vol. 2, no. 8, p. 518, 2013.

[17] A. Kassim, H. S. Min, T. W. Tee, and N. C. Fei, "Influence of triethanolamine on the chemical bath deposited NiS thin films," The American Journal of Applied Sciences, vol. 8, no. 4, pp. 359361, 2011.

[18] M. S. Shinde, P. B. Ahirrao, I. J. Patil, and R. S. Patil, "Thickness dependent electrical and optical properties of nanocrystalline copper sulphide thin films grown by simple chemical route," Indian Journal of Pure and Applied Physics, vol. 50, no. 9, pp. 657-660, 2011.

[19] H. Y. He, "Thermal-assisted chemical bath deposition and optical property of CuS films," Optoelectronics and Advanced Materials, Rapid Communications, vol. 5, no. 12, pp. 1301-1306, 2011.

[20] A. Kassim, H. S. Min, L. K. Siang, and S. Nagalingam, "Surface morphology of CuS thin films observed by atomic force microscopy," Journal for Science, vol. 16, pp. 24-33, 2011.

[21] B. Asenjo, C. Guilln, A. M. Chaparro et al., "Properties of $\operatorname{In}_{2} \mathrm{~S}_{3}$ thin films deposited onto ITO/glass substrates by chemical bath deposition," Journal of Physics and Chemistry of Solids, vol. 71, no. 12, pp. 1629-1633, 2010.

[22] S. M. U. Ishiwu, M. N. Nnabuchi, and C. N. Eze, "The effects of deposition and annealing temperature and time on the optical and solid state properties of cadmium selenide (CdSe) thin films grown by chemical bath deposition technique," Chalcogenide Letters, vol. 8, no. 1, pp. 59-64, 2011.

[23] E. Guneri, F. Gode, C. Ulutas, F. Kirmizigul, G. Altindemir, and C. Gumus, "Properties of p-type SnS thin films prepared by chemical bath deposition," Chalcogenide Letters, vol. 7, no. 12, pp. 685-694, 2010.

[24] A. Kassim, H. S. Min, L. Y. Yee, and S. Nagalingam, "Structural and morphological characterization of chemical bath deposition of FeS thin films in the presence of sodium tartrate as a complexing agent," Silpakorn University Science and Technology Journal, vol. 4, no. 2, pp. 36-42, 2010.

[25] F. I. Ezema, D. D. Hile, S. C. Ezugwu, R. U. Osuji, and P. U. Asogwa, "Optical properties of $\mathrm{CdS} / \mathrm{CS}$ and $\mathrm{CuS} / \mathrm{CdS}$ heterojunction thin film deposited by chemical deposition technique," Journal of Ovonic Research, vol. 6, no. 3, pp. 99-104, 2010.

[26] S. D. Chavhan and R. Sharma, "Growth, structural and optical properties of non-stoichiometric $\mathrm{CuIn}\left(\mathrm{S}_{1-x} \mathrm{Se}_{x}\right)_{2}$ thin films deposited by solution growth technique for photovoltaic application," Journal of Physics and Chemistry of Solids, vol. 67, no. 4, pp. 767-773, 2006.

[27] S. M. Reda and S. A. El-Sherbieny, "Dye-sensitized nanocrystalline CdS and ZnS solar cells with different organic dyes," Journal of Materials Research, vol. 25, no. 3, pp. 522-528, 2010.

[28] A. Kassim, H. S. Min, T. W. Tee, L. K. Siang, and S. Nagalingam, "Morphological characterization of Cus thin films by atomic force microscopy," Research Journal of Applied Sciences, Engineering and Technology, vol. 3, no. 6, pp. 513-518, 2011.

[29] M. Chen, J. Zhao, and X. Zhao, "Scanning electrochemical microscopy studies of micropatterned copper sulfide $\left(\mathrm{Cu}_{x} \mathrm{~S}\right)$ thin films fabricated by a wet chemistry method," Electrochimica Acta, vol. 56, no. 14, pp. 5016-5021, 2011.

[30] L. Isac, I. Popovici, A. Enesca, and A. Duta, "Copper sulfide $\left(\mathrm{Cu}_{x} \mathrm{~S}\right)$ thin films as possible pp-type absorbers in 3D solar cells," Energy Procedia, vol. 2, no. 1, pp. 71-78, 2010.

[31] T. Theivasanthi and M. Alagar, "An insight analysis of nano sized powder of jackfruit seed," Nano Biomedicine and Engineering, vol. 3, no. 3, pp. 163-168, 2011.

[32] I. A. Ezenwa, "Effects of deposition time on the absorbance of chemical bath deposited CuS thin films," Research Journal of Engineering Sciences, vol. 2, no. 1, pp. 1-4, 2013.

[33] P. P. Hankare, K. C. Rathod, M. R. Asabe et al., "Photoelectrochemical applications of $\mathrm{In}_{2} \mathrm{Se}_{3}$ thin films by chemical deposition," Journal of Materials Science: Materials in Electronics, vol. 22, no. 4, pp. 359-364, 2011.

[34] S. K. Mandal, S. Chaudhuri, and A. K. Pal, "Optical properties of nanocrystalline $\mathrm{ZnS}$ films prepared by high pressure magnetron sputtering," Thin Solid Films, vol. 350, no. 1, pp. 209-213, 1999.

[35] F. I. Ezema, A. B. C. Ekwealor, and R. U. Osuji, "Effect of thermal annealing on the band GAP and optical properties of chemical bath deposited ZnSe thin films," Turkish Journal of Physics, vol. 30, no. 3, pp. 157-163, 2006.

[36] P. K. Ghosh, S. Jana, V. N. Maity, and K. K. Chattopadyay, "Effect of particle size and inter-electrode distance on the fieldemission properties of nanocrystalline CdS thin films grown in a polymer matrix by chemical bath deposition," Physica E, vol. 35, no. 1, pp. 178-182, 2006.

[37] J. Barman, K. C. Sarma, M. Sarma, and K. Sarma, "Structural and optical studies of chemically prepared CdS nanocrystalline thin films," Indian Journal of Pure and Applied Physics, vol. 46, no. 5, pp. 339-343, 2008. 
[38] H. T. Grahn, Introduction to Semiconductor Physics, World Scientific Publishing, Singapore, 1999.

[39] A. Haldar, S. Maity, and N. B. Manik, "Effect of $\mathrm{C}_{60}$ on methyl red and crystal violet dye-doped photovoltaic device," Ionics, vol. 14, no. 3, pp. 263-267, 2008.

[40] M. Rusop, T. Shirata, P. M. Sirimanne, T. Soga, T. Jimbo, and M. Umeno, "Study on the properties and charge generation in dyesensitized n- $\mathrm{TiO}_{2} \mid$ dyelp-CuI solid state photovoltaic solar cells," Applied Surface Science, vol. 252, no. 20, pp. 7389-7396, 2006.

[41] P. M. Sirimanne, T. Shirata, T. Soga, and T. Jimbo, "Charge generation in a dye-sensitized solid-state cell under different modes of illumination," Journal of Solid State Chemistry, vol. 166, no. 1, pp. 142-147, 2002.

[42] G. R. A. Kumara, S. Kaneko, M. Okuya, B. Onwona-Agyeman, A. Konno, and K. Tennakone, "Shiso leaf pigments for dyesensitized solid-state solar cell," Solar Energy Materials and Solar Cells, vol. 90, no. 9, pp. 1220-1226, 2006. 

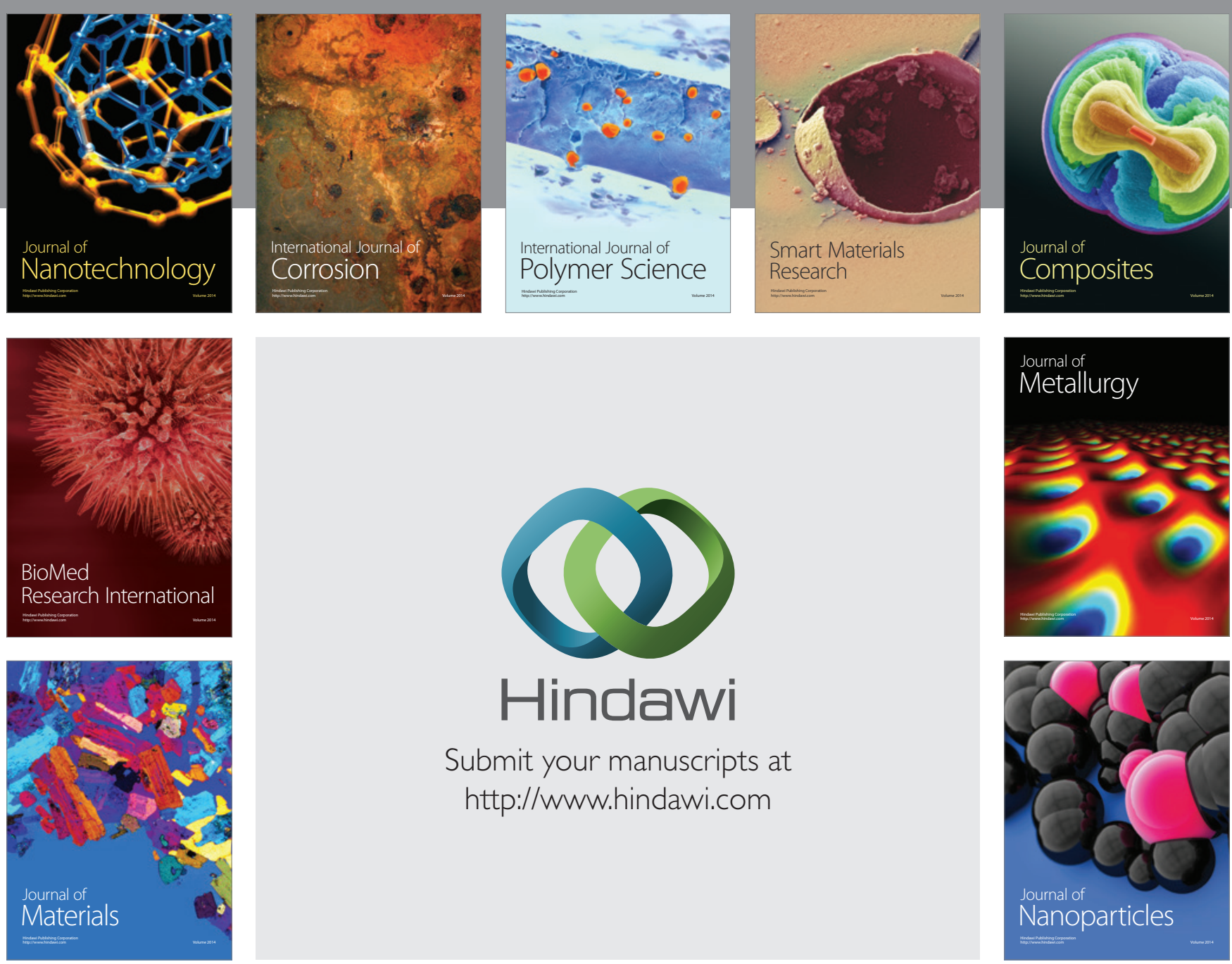

Submit your manuscripts at http://www.hindawi.com
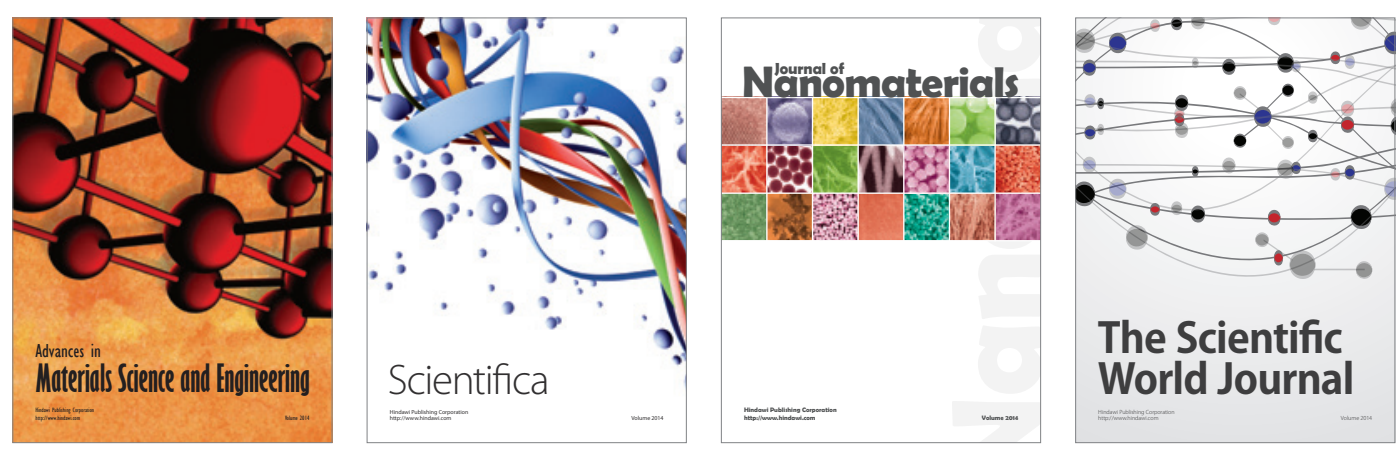

\section{The Scientific World Journal}
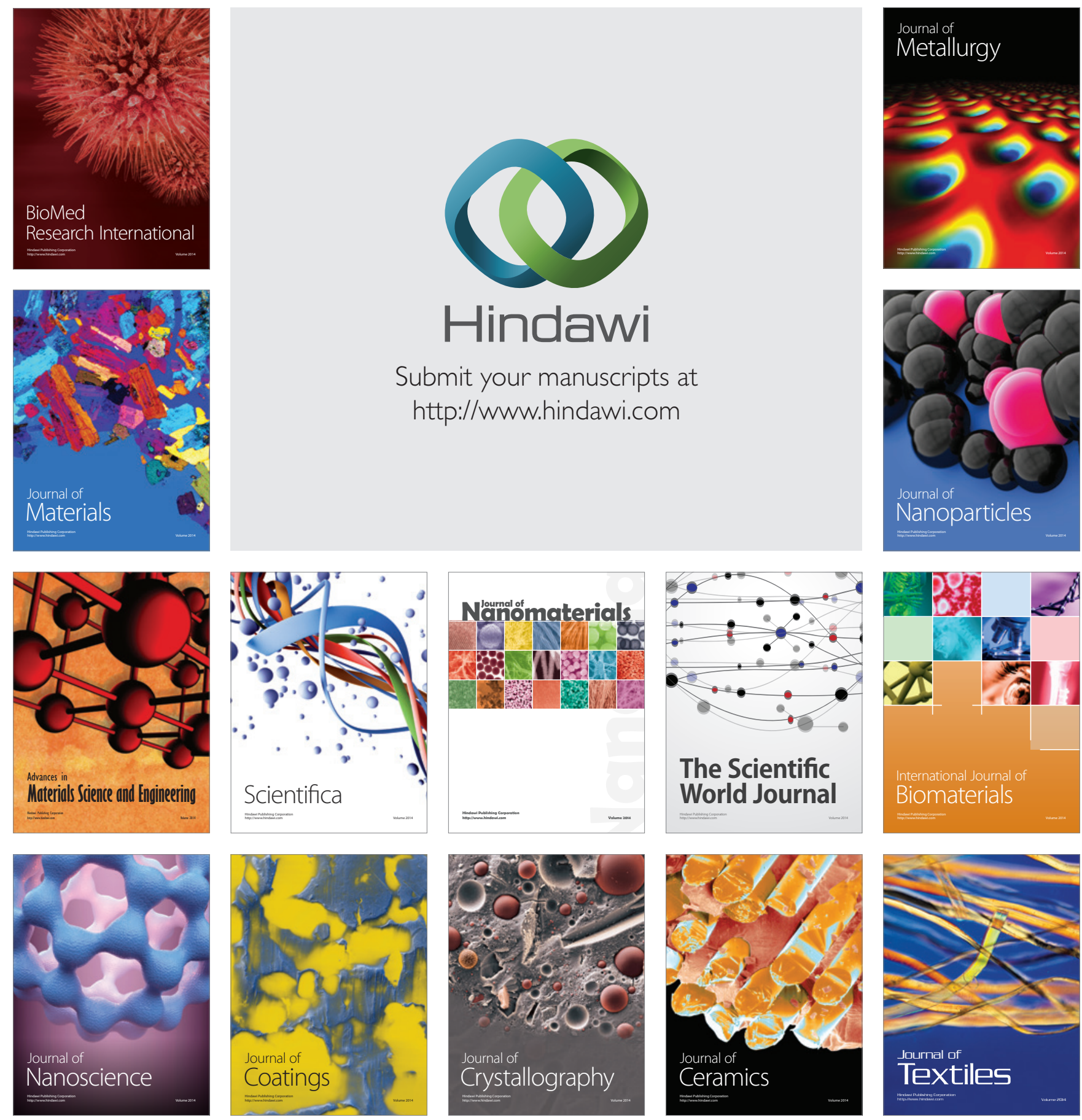